\title{
PARTISIPASI MASYARAKAT DALAM PELAKSANAAN MANAJEMEN \\ BERBASIS SEKOLAH DI SEKOLAH DASAR SUMATERA BARAT.
}

\author{
Oleh : Firman
}

\begin{abstract}
This study aimed to show that : (1) People participation in the implementation of MBS (Management Based School), and (2) The problem implementation of MBS at Elementary School in West Sumatra.This study used qualitative method and the implementation are selected purposively by snow ball technique. Collecting data are carried out by observation participant, interview and document analysis. The data is analyzed inductively to follow the model that used by Miles and Huberman (1992).Based on this study it show that : (1) People participation have not optimal yet to applicant MBS at Elementary School in West Sumatra because they still considered that they only as motivator in the education implementation fluently at Elementary School, (2) The unit who responsible in sosialize the MBS and the coordination between school, DIKNAS, and society have not optimal yet. The cooperation network was implemented still by student' parents whereas people like in the LSM, entrepreneur, government instantion or private entrepreneur, Lembaga Kerapatan Adat Nagari, Majelis Ulama Indonesia have not performed yet. Meanwhile people feel confused to join in MBS implementation at Elementary School West Sumatra.
\end{abstract}

(Kata Kunci : Partisipasi, Manajemen Berbasis Sekolah dan Masyarakat Minangkabau).

\section{A. Pendahuluan}

Pembagunan merupakan proses perubahan dalam masyarakat, dimana kemiskinan dihapuskan, kreatifitas serta pengetahuan masyarakat ditingkatkan menuju kemandirian dan kemakmuran. Pengalaman yang ditempuh dalam pembagunan Pendidikan Indonesia selama ini, bersifat sentralistik serta kurang menumbuhkan kemandirian. Sekolah masa silam merupakan pepanjang tangan birokrasi pemerintah pusat dalam pelaksanaan pendidikan dan kebijakan pendidikan berada pada pemerintah pusat. Pengelolaan pendidikan yang bersifat sentralistik tesebut, membuat kepala sekolah/guru kurang kreatif mengelola dan memenej pendidikan yang dilaksanakan sekolahnya masing-masing. Tekanan birokrasi menyebabkan transparansi kurang berkembang serta peran orang tua dan masyarakat 
hanya sebatas membayar iuran BP3 serta membelikan seragam sekolah, banyak aspirasi masyarakat di daerah kurang jadi pertimbangan dalam pelaksanaan pendidikan. Semua kebijakan harus dilaksanakan berdasarkan Juklah (Petunjuk Pelaksanaan) dan Juknis (Petunjuk Teknis) yang ada. Selanjutnya anggaran pendidikan diturunkan dari pusat ke daerah melalui jalur birokrasi yang berbelit-belit dan tidak jarang anggaran tersebut setelah sampai ke sekolah-sekolah tidak sesuai dengan jumlah yang telah ditetapkan.

Sehubungan dengan hal itu, Hasri (2004:1) menjelaskan perlu dilakukan upaya-upaya perbaikan pelaksanaan pendidikan, salah satunya dengan melakukan reorientasi penyelenggaraan pendidikan. Di era otonomi daerah sesuai dengan pasal 11 ayat 2 UU Nomor 22 tahun 1999, bidang pendidikan adalah merupakan kewenangan pemerintah Kabupaten/Kota, termasuk dalam peningkatan mutu. Manajemen Berbasis Sekolah (MBS) dipilih sebagai model desentralisasi pendidikan dasar dan menengah karena diyakini model ini akan mampu meningkatkan kinerja sekolah, mempermudah pencapaian tujuan dan peningkatan mutu pendidikan.

Manajemen berbasis sekolah dapat diartikan sebagai model manajemen yang memberikan otonomi lebih besar kepada sekolah dan mendorong pengambilan keputusan partisipatif dengan melibatkan warga sekolah (guru, siswa, kepala sekolah, karyawan, orang tua, dan masyarakat) untuk meningkatkan mutu berdasarkan kebijakan pendidikan nasional (Arifin: 1996).

Manajemen Peningkatan Mutu Berbasis Sekolah lebih lanjut disebut dengan MBS adalah strategi untuk meningkatkan pendidikan dengan mendelegasikan kewenangan pengambilan keputusan penting dari pusat dan daerah ke tingkat sekolah. Oleh karena itu, MBS pada dasarnya merupakan sistem manajemen di mana sekolah merupakan unit pengambilan keputusan penting tentang penyelenggaraan pendidikan secara mandiri. MBS memberikan kesempatan pengendalian lebih besar bagi kepala sekolah, guru, murid, dan orang tua atas proses pendidikan di sekolah .

Pelaksanaam MBS membuat sekolah memiliki keleluasaan dalam pengambilan keputusan tentang pengelolaan sumberdaya dan kurikulum secara profesional. Peran aktif masyarakat diperlukan baik dalam hal pemenuhan kebutuhan 
sekolah, pengambilan keputusan maupun pengawasan dan pemantauan pelaksanaan pendidikan di sekolah (Arifin, 1996).

Partisipasi masyarakat dalam pelaksanaan pendidikan di daerah akan mendorong pengelolaan pendidikan di sekolah secara transparan dan demokratis, serta menghilangkan monopoli pengelolaan pendidikan. Sehubungan dengan hal itu, pengelolaan pendidikan dikembalikan kepada masyarakat untuk berperan aktif bersama sekolah dan pemerintah dalam pelaksanaan pendidikan. Keterlibatan guru, orang tua, dan anggota masyarakat lainnya dalam pengambilan keputusan, MBS dipandang dapat menciptakan lingkungan belajar yang efektif.

Partisipasi masyarakat dalam pelaksanaan MBS adalah ikut sertanya masyarakat dalam pelaksanaan MBS mulai dari perencanaan, implementasi, penilaian sekaligus ikut serta memanfaatkan dan menikmati hasil secara nyata. Soetrisno ( 1993 ; 125 ) mengungkapkan partisipasi masyarakat dalam pembangunan dapat tercipta apabila masyarakat diikutsertakan dalam tahap perencanaan, pelaksanaan, pengawasan, dan pemanfaatan sekaligus menikmati hasil pembangunan secara nyata. Pentingnya keterlibatan masyarakat pada tahap perencanaan program, terutama dalam menentukan alternatif tujuan yang akan dicapai.

Emrich (Piliang,2004: 3) mengusulkan beberapa pedoman dalam penyusunan kebijaksanaan yang berisi peningkatan partisipasi, yaitu : (1) partisipasi harus dimulai dari tingkat bawah, (2) partisipasi harus terjadi pada semua tahap proses pembangunan, (3) suara dukungan semata-mata bukanlah partisipasi, (4) partisipasi harus mendukung isu berupa program-program nyata di bidang produksi dan distribusi, (5) partisipasi harus mengubah loyalitas organisasi atau kelompok yang sudah ada, (6) peningkatan partisipasi akan mengundang tantangan dari pihakpihak tertentu

Berkaitan dengan hal itu, Hasri (2004:7) menjelaskan dari hasil sosialisasi melalui media cetak berupa buku panduan "Manajemen Peningkatan Mutu Berbasis Sekolah" oleh Depdikbud 1999 yang telah diperbaharui tahun 2001, dan melalui penerapan MBS yang telah berjalan selama 3 tahun di beberapa sekolah dasar (SD), ternyata MBS masih dipersepsikan berbeda oleh Pemerintah Daerah, Sekolah dan masyarakat. Hal ini terlihat dari fenomena sebagai berikut, yaitu: (1) meningkatnya 
biaya pendidikan yang dikenakan kepada wali murid, (2) seorang guru di SD (negeri) di mana kebijakan MBS di implementasikan mempersepsikan penerapkan MBS agar diikuti dengan peningkatan kualitas kerja guru serta diperlukan biaya yang besar dan hal ini sangat memberatkan, (3) seorang Kepala Sekolah menganggap MBS pada dasarnya, adalah transparansi segala hal dan berhubungan dengan upaya pembentukan kemandirian suatu sekolah, dan (4) ada juga yang menganggap MBS pada hakikatnya adalah swastanisasi, bahkan ada gelagat MBS dijadikan alasan untuk menjadikan sekolah semacam badan usaha milik negara.

Masyarakat berpandangan MBS nama lain dari BP3 dan kinerja sekolah tidak jauh berbeda. Peranserta masyarakat di Sumatera Barat yang sebagian besar berbudaya Minangkabau dalam pendidikan dan pengambilan keputusan mencapai tujuan pendidikan di sekolah dewasa ini kurang terwujud. Berbagai potensi masyarakat, diantaranya : Niniak Mamak (Ninik Mamak), Alim Ulama dan Cadiak Pandai (Cerdik Pandai) belum terakumulasi secara optimal dalam penerapan MBS di Sumatera Barat. Begitu juga pengambilan keputusan bersifat demokratis sebagai salah satu ciri dari masyarakat Minangkabau, sesuai dengan fatwa adat : Bulek ai dek pambuluah, bulek kato dek mufakat, (Kata sepakat diperoleh melalui musyawarah). Lamak dek awak, katuju dek urang (Sama-sama enak untuk semua orang), dalam konteks pemerintahan Nagari belum terwujud secara optimal dalam penerapan MBS di Minangkabau.

Bertitik tolak dari hal itu, menarik ditelusuri lebih lanjut melalui penelitian ini, bagaimana partisipasi masyarakat dalam pelaksanaan Manajemen Berbasis Sekolah (MBS) di Sekolah Dasar Propinsi Sumatera Barat. Penelitian ini bermanfaat untuk mengevalusi lebih lanjut penerapan program MBS di Sekolah Dasar Propinsi Sumatera Barat yang masyarakatnya sebagian besar berbudaya Minangkabau.

\section{B. Metode Penelitian}

Penelitian ini menggunakan metode kualitatif, dengan Lokasi Kecamatan Padang Barat Kota Padang dan Kecamatan IV Candung Kabupaten Agam. Pemilihan informan dilakukan secara purposive, dengan teknik bola salju. Pengumpulan data dilakukan dengan partisipan observasi, wawancara dan analisis dukumen. Data 
dianalisis secara induktif, dengan melakukan langkah utama membuat klasifikasi, merumuskan kategori-kategori sampai kepada penafsiran arti data yang ada. Model digunakan dalam menganalisis data adalah pola yang dikembangkan oleh Miles dan Huberman (1992:22), dengan kegiatan: (1) reduksi data, (2) penyajian data, (3) penarikan kesimpulan dan verifikasi, (4) merumuskan temuan, (5) membuat laporan hasil penelitian. Pengumpulan dan analisis data dilakukan selama dan sesudah selesai proses penelitian.

\section{Hasil Penelitian dan Pembahasan}

\section{Hasil Penelitian}

\section{a. Partisipasi Masyarakat dalam Pelaksanaan MBS di SD Sumbar}

Sebagian besar murid SD di Kecamatan Padang Barat Kota Padang adalah etnis Minangkabau dan berasal dari Kota/Kabupaten yang ada di Sumatera Barat serta tinggal terpencar dari berbagai Kecamatan yang ada di Kota Padang. Masyarakat Minangkabau di Kota Padang berbeda dengan daerah lainnya di Sumbar, mereka diikat oleh pemerintahan Kelurahan yang terbagi ke RW dan RT. Walaupun mereka hidup di lingkungan perkotaan, pengambilan keputusan/penyelesaian permasalahan tetap berlandaskan kepada nilai-nilai budaya Minangkabau, sesuai dengan fatwa adat: Bungka ganok manahan asah, Ameh batuah manahan uji, Kato bana manahan sudi, Hukum adis manahan bantiang (Bungkal genap menahan asah, Emas berbuah menahan uji, Kata benar menahan sudi, Hukum banding menahan banding).

Berdasarkan hasil pengumpulan data ditemukan masyarakat di lokasi penelitian kurang mengetahui MBS. Istilah MBS diketahui melalui rapat-rapat komite sekolah, walaupun demikian apa yang harus dilakukan untuk pelaksanaan MBS belum diketahui secara pasti dan pelaksaan MBS diperlukan komite sekolah.

Pemilihan Komite Sekolah dilakukan secara musyawah dengan orang tua murid lainnya. Keterlibatan pembuka masyarakat, yang terdiri dari: niniak 
mamak, alim ulama dan cadiak pandai (cerdik pandai), bundokanduan serta anak nagari kurang terakumulasi dalam pembentukan komite sekolah. Pembentukan komite sekolah dilakukan dengan membagi undangan kepada seluruh orang tua murid yang bersekolah di SD lokasi penelitian. Setelah panitia dibentuk, lalu mengadakan musyawarah untuk mempersiapan pembangunan sarana dan prasarana sekolah yang menunjang PBM. Sarana-prasarana yang dimaksud, antara lain: meja dan kursi belajar murid, papan tulis, dan perbaikan bangunan fisik sekolah lainnya.

Apabila orang tua wali murid sebagai anggota komite sekolah tidak mau berpartisipasi aktif dalam penyediaan sarana pendidikan di butuhkan sekolah tersebut, menjadi gunjingan serta tudingan di dalam rapat-rapat komite sekolah. Muara akhir tidak jarang teguran pembayaran kewajiban tersebut disampaikan oleh kepala sekolah melalui siswa kepada orang tua wali murid. Tidak jarang kewajiban pembayaran iyuran dikaitkan dengan penerimaan laporan studi diakhir semester atau tahun ajaran.

Kondisinya berbeda dengan SD lokasi penelitian di Kecamatan IV Angkat Candung, SD lokasi penelitian telah memiliki komite sekolah yang beranggotakan pemuka masyarakat, teridiri dari tokoh masyarakat, seperti : niniak mamak, alim ulama dan cadiak pandai (cerdik pandai), bundokanduan serta anak nagari, di samping orang tua wali murid. Penggalang dana untuk membantu kelengkapan sarana pendidikan tidak jarang dilakukan melalui pemanfaatan potensi yang ada di nagari. Bantuan dana tidak saja diharapkan dari orang tua murid tetapi juga diperoleh dari batuan masyarakat nagari tersebut dari rantau di seluruh pelosok tanah air. Ketua Komite Sekolah berpandangan : $\mathrm{Ka}$ mudiak sarantak galah, Ka hilia sarangkuah dayuang, Sakato muluik jo hati, Sasuai lahia jo batin ( Ke mudik sehentak galah, Ke hilir serengkuh dayung, Sekata mulut dengan hati, Sesuai lahir dengan batin).

Sehubungan dengan hal itu, Pemerintahan Nagari mendata seluruh penduduknya yang ada di rantau dan di nagari, kemudian mengajukan formulis isian untuk membantu dana operasional pendidikan. Kebijakan tersebut sebelumnya telah dirumuskan melalui rapat dengan wali murid serta pemuka 
masyarakat yang ada di setiap nagari. Wali Nagari di lokasi penelitian berpandangan : Sakik basilau, Mati bajanguak, Alek bapanggiah, mati bajirambok, Nan elok bahimbauan, Nan buruak bahambauan (Sakit disilau, Mati dilayat, Helat dipanggil, Mati diselamatkan, Yang baik berhimbauan, Yang buruk berhamburan ). Kebersamaan merupakan dasar kasih sayang yang diharapkan Wali Nagari di lokasi penelitian terwujud dalam kehidupan masyakatnya. Untuk itu Wali Nagari menjalankan perannya sesuai dengan fatwa adat : Lupo diingekkan, Talamun dikakeh, Tarapuang dikaik, Tabanam basilami (Lupa diingatkan, terlamun dikais, Terapung dikait, Terbenam diselami). Dana yang diperoleh dari perantauan serta donatur lainnya tersebut, sebagian besar digunakan untuk perbaikan fisik dan tidak bersifat rutin.

Apabila diadakan rapat untuk merencanakan pembangunan fisik dan peningkatan PBM di SD lokasi penelitian, ditemukan tidak banyak di antara orang-orang yang dipilih sebagai panitia tersebut meluangkan waktunya menghadiri rapat-rapat membicarakan berbagai pembenahan pembangunan fisik SD dan peningkatan kualitas PBM. Dari sejumlah orang yang menghadiri rapat, ada beberapa di antaranya meninggalkan rapat ketika rapat berlangsung. Apabila ditelusuri lebih lanjut diperoleh informasi, penyebab gejala tersebut adalah masyarakat memandang kegiatan di sekolah dan pelaksanaan PBM merupakan tanggung jawab kepala sekolah dan guru. Aktifitas komite sekolah membantu kepala sekolah dalam kelancaran pendidikan di sekolah.

Sumbangan pemikiran dalam rapat umumnya diberikan oleh orangorang tertentu saja Terlihat di sini, ada semacam dominasi pendapat pada sebagian kecil orang yang memiliki peran hirarkis yang lebih tinggi pada struktur kekuasaan, selebihnya cenderung memposisikan diri pada pihak yang memberikan dukungan terhadap pendapat yang berkembang. Akhirnya setiap isuisu pembangunan dan rencana-rencana pembangunan SD, merupakan kehendak sekelompok kecil orang yang berada di lingkaran kekuasaan di sekolah.

Partisipasi masyarakat dalam merencanakan dan pelaksanaan program pembangunan pendidikan di SD tidak terwujud. Sebagian besar informan 
berpandangan pembangunan sekolah adalah urusan pemerintah dan masyarakat sifatnya hanya mendukung saja. Kondisi ini menyebabkan pemeliharaan fasilitas yang sudah ada sangat rendah. Misalnya, membuat pagar pengamanan dari hewan ternak serta pemeliharaan kebersihan lingkungan. Akhirnya fasilitas yang semestinya dapat dimanfaat dalam waktu lama, rusak sebelum waktunya.

Komite sekolah sebagian besar belum mengarah kepada peningkatan mutu PBM, seperti penyediaan buku-buku, media pembelajaran dan isi pembelajaran. Berdasarkan informasi yang diperoleh ditemukan, komite sekolah sehubungan dengan pelajaran Budaya Alam Minangkabau (BAM) sangat dibutuhkan siswa di sekolah, tetapi tidak dapat dipenuhi karena masyarakat tidak mengetahui cara berpartisipasi dalam PBM. Kondisi semacam ini, menyebabkan materi pelajaran BAM sebagian besar diperoleh dari buku bacaan yang ada dan tidak berdasarkan budaya yang tumbuh dalam kehidupan masyarakat. Kenyatan yang ditemui tidak semua guru memahami konsep-konsep BAM. Misalnya, konsep sistem kekerabatan dan hubungannya dengan pola pewarisan, Islam dan adat Minangkabau, tata krama dan adat istiadat Minangkabau serta perubahan kebudayaan dalam masyarakat. Begitu juga PBM dalam mata pelajaran lainnya.

Dengan demikian dapat disimpulkan partisipisi masyarakat dalam pelaksanaan pendidikan baru sebatas dukungan dana dalam pembangunan fisik sekolah. Peran serta masyarakat melalui komite sekolah dalam penyediaan buku, media pengajaran dan isi PBM belm menjadi perioritas utama. Kondisi ini disebabkan karena masyarakat beranggapan kegiatan yang mereka lakukan hanya sekedar mendukung kegiatan yang dilakukan pemerintah, kepala sekolah/guru dalam pelaksanaan pendidikan.

\section{b. Permasalahan Peningkatan Partisipasi Masyarakat dalam Pelaksanaan MBS di SD.}

Berdasarkan informasi di lokasi penelitian ditemukan, kendala pelaksanaan MBS adalah: tidak jelas unit yang bertanggung jawab dalam mensosialisasikan MBS serta koordinasi antara sekolah, Diknas dan masyarakat 
belum optimal. Walaupun demikian kebijakan MBS telah diimplementasikan ke seluruh SD di Sumbar. Kebijakan MBS tersebut seharusnya dilaksanakan dengan memfungsikan seluruh komponen, sehingga seluruh elemen dapat berpartisipasi aktif, seperti : alim ulama, cadiak pandai, niniak mamak, bundo kanduang di lingkungan masyarakat Minangkabau. Kebersamaan seperti yang diungkapkan fatwa adat : Ka mudiak sarantak galah, Ka hilia sarangkuah dayuang, Sakato muluik jo hati, Sasuai lahia jo batin (Ke mudik sehentak galah, Ke hilir serengkuh dayung, Sekata mulut dengan hati, Sesuai lahir dengan batin) dapat terwujud dalam mengimpilimentasikan MBS di SD Sumbar.

Jaringan kerjasama yang dilakukan masih terbatas hanya dengan orang tua siswa, dengan institusi yang ada di masyarakat, seperti dengan Lembaga Swadaya Masyarakat (LSM), pihak pengusaha, Lembaga Kerapatan Adat Nagari, Majlis Ulama Indonensia (MUI) belum dilakukan oleh sekolah. Peran serta masyarakat yang sebagian besar berbudaya Minangkabau dalam pendidikan dan pengambilan keputusan untuk mencapai tujuan pendidikan kurang terwujud.

Sebagian perencanaan dan pengambilan keputusan dilakukan oleh Kepala Sekolah dan Pengurus Komite Sekolah. Tidak jarang keputusan yang diambil tidak sesuai dengan situasi dan kondisi, sehingga orang tua dan masyarakat merasa diperlakukan semena-mena. Hal ini sesuai dengan fatwa adat : Harimau jan tadorong dek balangnyo, Gajah jan tadorong dek balalainya, Kok gadang jan malendo.Tinggi jan mangimpik. Panajang jan malilik (Harimau jangan membanggakan belangnya,Gajah jangan membanggakan belalainya.Kalau besar jangan melanda, Kalau cerdik jangan menjual, Tinggi jangan menghimpit, Panjang jangan melilit).

Apabila dicermati lebih lanjut, permasalahan pendidikan menjadi pembicaraan masyarakat dimana-mana, mulai dari Lapau (kedai kopi) sampai kepada seminar yang dilaksanakan dengan melibatkan pakar maupun pemuka adat. Semua masyarakat Minangkabau yang berada di kampung maupun di rantau merasa terpanggil terhadap pelaksanaan pendidikan di Sumbar. Hal ini didorong oleh nilai budaya sebagai berikut : Hujan batu di nagari awak, hujan ameh di nagari urang, namun kampuang takana juo (Hujan batu di negeri kita, 
hujan emas di negeri orang, namun kampung teringat jua). Dorong-dorongan tersebutlah pada prinsipnya modal dasar bagi masyarakat Minangkabau membangun SDM yang ada.

Nilai-nilai yang bertumpu dalam kehidupan masyarakata Minangkabau tersebut tidak tersalurkan secara optimal dalam implikasi MBS di SD Sumbar. Pembuka masyarakat, seperti Ninik Mamak, Alim Ulama, Cadiak Pandai dan Bundo Kanduang merasa asing dan kebigungan untuk mengambil peran dalam peningkatan mutu, efesiensi dan efektifitas pelaksansaan pendidikan di Sekolah. Sipirit untuk berkorban demi kepentingan masyarakat yang bersumber dari nlainilai budaya Minangkabau, seperti fatwa adat : Tagak kampuang mamaga kampuang, Tagak suku mamaga suku. Tagak nagari mamaga nagari. Tagak banso mamaga bangso ( Tegak kampung memagar kampung, Tegak suku memagar suku, Tegak negeri memagar negeri, tegak bangsa memangar bangsa) tidak dapat tumbuh dengan subur dalam pelaksanaan pendidikan di Sumbar deasa ini.

Begitu juga pengambilan keputusan bersifat demokratis sebagai salah satu ciri dari masyarakat Minangkabau, sesuai dengan fatwa adat : Baiyo-iyo jo adiak, Batido-tido jo kakak.Elok diambiak jo mufakaik. Buruak dibuang jo hentakan (Berunding dengan adik, Bermusyawarah dengan kakak, Baik diambil dengan mufakat, Buruk diabuang dengan hitungan). Begitu juga dalam pengambilan keputusan tidak dilandaskan kepada nilai budaya yang hidup dalam masyarakat Minangkabau : Bulek ai dek pambuluah, bulek kato dek mufakat, Bilek baru digolongkan, Pipih baru dilayangkan, (Kata sepakat diperoleh melalui musyawarah). Lamak dek awak, katuju dek urang (Sama-sama enak untuk semua orang), dalam konteks pemerintahan Nagari belum terwujud secara optimal dalam penerapan MBS di Minangkabau.

Kondisi tersebut di atas, menyebabkan segala potensi yang ada di lingkungan masyarakat Minangkabau untuk meningkatkan kemandirian sekolah dalam mewujudkan efektifitas dan efesiensi pelaksanaan pendidikan tidak 
terlaksana. Jurang pemisah antara sekolah dan masyarakat terjadi dan banyak kebijakan-kebijakan sekolah kurang dapat didukung masyarakat secara optimal.

\section{Pembahasan}

Berdasarkan penelitian ditemukan partisipasi masyarakat dalam pelaksanaan MBS di SD Sumbar belum optimal, sehingga potensi yang ada dalam masyarakat Minangkabau belum dapat dimanfaatkan secara optimal dalam peningkatan kualitas pendidikan dasar. Kurangnya optimalnya partisipasi masyarakat dalam pelaksanaan MBS tersebut, disebabkan kurangnya sosialisasi kebijakan dari pemerintah pada tataran masyarakat. Paradigma pembangunan dengan strategi pemberdayaan masyarakat berorientasi pada kebutuhan, partisipasi, keterpaduan, berkelanjutan, keserasian, serta kemandirian belum terwujud.

Supriatna $(2000 ; 115)$ menjelaskan pembangunan masyarakat merupakan aktifitas masyarakat berdasarkan prakarsa, inisiatif, kreativitas dan kemandiriannya bersama-sama kegiatan pemerintah untuk memperbaiki kondisi sosial budaya dan ekonomi masyarakat yang bersangkutan.

Keberhasilan pelaksanaan MBS dalam pembangunan pendidikan dasar ditentukan oleh partisipasi masyarakat memperbaiki kehidupanya atas dasar kekuatan dan kemampuan sendiri. Upaya tersebut dapat diwujudkan dalam bentuk perencanaan program didasarkan pada pemberdayaan melalui bimbingan, pembinaan, dan bantuan teknis dari pemerintah.

Ndraha $(1987$; 55) menjelaskan jika masyarakat tidak berkesempatan berpartisipasi dalam program pembangunan di daerahnya maka proyek-proyek pembangunan kurang berjalan dengan lancar. Lebih tegas lagi dapat dikatakan bahwa partisipasi masyarakat dapat dijadikan sebagai tolok ukur dalam memulai apakah proyek pembangunan yang bersangkutan merupakan proyek pembangunan daerahnya atau bukan. 
Pembangunan sebagai proses peningkatan kemampuan manusia untuk menentukan masa depannya mengandung arti bahwa masyarakat perlu dilibatkan dalam proses pengambilan keputusan pada tahap perencanaan. Dalam hal ini masyarakat perlu diberi kewenangan agar dapat berpartisipasi dalam menetukan pilihan-pilihannya sesuai dengan kebutuhan mereka secara bersama. Bryant dan Louise $(1989$; 105) menjelaskan pembangunan yang berpusat pada diri manusia dengan mengembangkan kemampuan untuk melihat hari esok yang lebih baik yang memerlukan keikut sertaan masyarakat pada setiap tingkat dalam proses pembangunan.

Partisipasi masyarakat dalam perencanaan dan pelaksanaan pendidikan di SD dapat mengembangkan kemandirian yang dibutuhkan oleh para anggota masyarakat demi tercapainya tujuan dan sasaran pelaksanaan MBS. Mengingat pentingnya partisipasi masyarakat pada tahap prencanaan dalam hal ini Conyers (Supriatna, 2000 ; 155) mengemukakan beberapa alasan antara lain : (1) partisipasi masyarakat merupakan suatu alat guna memperoleh informasi mengenai kondisi, kebutuhan dan sikap masyarakat, (2) masyarakat akan lebih mempercayai program atau proyek pembangunan tersebut jika mereka merasa dilibatkan dalam proses persiapan dan perencanaannya karena mereka juga lebih mengetahui dan merasa memiliki terhadap proyek atau program tersebut, serta (3) adanya anggapan nilai-nilai demokrasi dapat direalisasi apabila masyarakat dilibatkan dalam pembangunan di daerahnya.

Pada tahap perencanaan atau program pembangunan biasanya dapat dilakukan melalui suatu kegiatan dengan menentukan sasaran-sasaran secara garis besar, baik di bidang sosial maupun ekonomi. Sebagai pelaku dalam proses perencanaan, pemerintah bersama masyarakat dapat melakukan suatu pertemuan untuk membicarakan masalah-masalah pelaksanaan MBS di sekolah bersangkutan

Kartasasmita (1997 ; 49) menjelaskan di dalam proses perencanaan pembangunan pada umumnya harus memiliki, mengetahui dan memperhitungkan beberapa unsur pokok antara lain: (1) tujuan akhir yang dikehendaki, (2) sasaransasaran dan prioritas untuk mewujudkannya, (3) jangka waktu mencapai sasaran- 
sasaran tersebut, (4) masalah-masalah yang dihadapi, (5) modal dan sumber daya yang akan digunakan serta pengalokasiannya, (6) kebijaksanaan-kebijaksanaan untuk melaksanakannya, (7) orang atau masyarakat dan organisasi atau badan pelaksananya, (8) mekanisme pemantauan, evaluasi dan pengawasan pelaksanaannya.

Selanjutnya Kartasasmita juga menjelaskan terdapat beberapa prinsip yang menunjukkan bahwa perencanaan dilaksanakan dengan ideal, yaitu: (1) prinsip partisipatif menunjukkan masyarakat yang akan diuntungkan atau manfaat dari program harus turut serta dalam proses perencanaan, (2) prinsip kesinambungan menunjukkan bahwa perencanaan tidak hanya berhenti pada satu tahap melainkan harus berlanjut sehingga menjamin adanya kemajuan terus menerus dalam mencapai kesejahteraan, (3) prinsip holistik menunjukkan bahwa masalah dalam perencanaan dan pelaksanaannya tidak dapat hanya dilihat dari satu sisi atau satu sektor tetapi harus dilihat dari berbagai aspek dan dalam keutuhan konsep secara keseluruhan.

Kurang optimalnya partisipasi masyarakat dalam pelaksanaan MBS di SD Sumbar, disebabkan unit yang bertanggung jawab dalam mensosialisasikan MBS serta koordinasi antara sekolah, Diknas dan masyarakat belum optimal. Jaringan kerjasama yang dilakukan masih dengan orang tua siswa, dengan masyarakat dalam arti kata luas, seperti dengan Lembaga Swadaya Masyarakat (LSM), pihak pengusaha, Instansi lainnya, Lembaga Kerapatan Adat Nagari, Majlis Ulama Indonensia (MUI) belum terwujud dan peran yang harus dilakukan masyarakat kebigungan pelaksanaan MBS di SD belum dimengerti secara optimal.

\section{Kesimpulan dan Saran}

\section{Kesimpulan}

Berdasarkan temuan penelitian dan pembahasan dapat disimpulkan hal-hal sebagai berikut 
(1) Partisipasi masyarakat dalam penerapan MBS di SD Sumbar belum optimal, karena masyarakat masih beranggapan bahwa mereka hanya sebagai pendukung kelancaran pelaksanaan pendidikan di SD.

(2) Unit yang bertanggung jawab dalam mensosialisasikan MBS serta koordinasi antara sekolah, Diknas dan masyarakat belum optimal. Jaringan kerjasama yang dilakukan masih dengan orang tua siswa, sedangkan dengan masyarakat dalam arti luas, seperti dengan Lembaga Swadaya Masyarakat (LSM), pihak pengusaha, instansi lainnya, Lembaga Kerapatan Adat Nagari, Majlis Ulama Indonensia (MUI) belum terwujud dan masyarakat kebigungan untuk berperan serta dalam pelaksanaan MBS di SD Sumbar.

\section{Saran}

Berdasarkan temuan penelitian tersebut di atas dapat direkomendasikan sebagai berikut :

1. Perlu dilakukan secara intensif peningkatan sosialisasi tentang MBS kepada masyarakat, melalui penataran/pelatihan kepada tokoh-tokoh masyarakat, liflet dan penyuluhan melalui media masa.

2. Kemampuan manajerial kepala sekolah perlu ditingkatkan melalui penataran tentang: transparansi dan akuntabilitas, perencanaan dan evaluasi sumber daya pendidikan dalam organisasi.

3. Perlunya pemberdayaan LKAAM, MUI, LSM dan Bundokanduang dalam menggerakan partisipasi masyarakan untuk pelaksanaan MBS di sekolah dasar.

4. Penataran tentang MBS perlu didasarkan oleh analisis kebutuhan penerapan MBS di sekolah.

5. Perlu menetapkan pilot proyek dan melaksanakan proyek penerapan MBS menimal 2 sekolah pada satu Kabupaten/Kota di Sumatera Barat. Selanjutnya secara kontiniu diadakan perlombaan dan studi banding antar sekolah. 


\section{Daftar Kepustakaan.}

Arifin, Zaenal (1996) : Jika Sekolah Tak Lagi Diminati. Suara Merdeka, hal.6

Bryant, Coralie \& Louise, White, (1989) : Manajemen untuk Negara Berkembang (terjemahan L.Rusyanto). Jakarta : LP3ES.

Hasri, Salfen, Firman, Helis Setiani dan Akhramer, (2004) : Implikasi Manajemen Berbasis Sekolah di Sumatera Barat. Padang : Balitbang Propinsi Sumatera Barat.

Kartasasmita, Ginandjar, (1996) :Pembangunan untuk Rakyat: Memadukan Pertumbuhan dan Pemerataan. Jakarta : Pustaka Cidesindo

Miles, M.B.dan Huberman, M. (1992) : Analisis Data Kualitatif. (terjemahan oleh Tjetjep Rohendi Rohidi) Jakarta: UI Press

Ndraha,Taliziduhu, (1987) : Pembangunan Masyarakat. Jakarta : Bina Aksara

Piliang,Hasrul, Firman dan Andi Bastian, (2004) : Partisipasi Masyarakat dalam Pelaksanaan Pembagunan Prasarana Sosial di Minangkabau. Padang : Balitbang Propinsi Sumatera Barat.

Soetrisno, Lukman . (1993) Menuju Masyarakat Partisipatif. Yogyakarta: Kanasius.

Supriatna, Tjahya (2000) : Strategi Pembangunan dan Kemiskinan. Jakarta : Rineka Cipta

\section{Curiculum Vitae}

Nama : Firman. Lahir tanggal 25 Februari 1961 di Koto Tuo, Agam dan Menamatkan pendidikan dasar di SD Negeri Koto Tuo, IV Angkat Candung Kabupaten Agam, SMP Negeri No.VI Bukittinggi, SPG Negeri Bukittinggi, Sarjana Pendidikan Jurusan Bimbingan Konseling FIP IKIP Padang tahun 1985, Magister Psikologi Sosial PPS Univ. Padjadjaran Bandung tahun 1992 dan Doktor Ilmu-Ilmu Sosial Univ.Airlangga Surabaya tahun 1997. Sekarang bertugas sebagai dosen jurusan Bimbingan dan Konseling serta PPS Univ. Negeri Padang. 
